\title{
Biodegradation of dicofol by Microbacterium sp. D-2 isolated from pesticide-contaminated agricultural soil
}

\author{
Peng Lu* ${ }^{*}$, Hong-ming Liu and Ai-min Liu
}

\begin{abstract}
Dicofol is an organochlorine insecticide widely used to prevent pests worldwide. Consequently, serious environmental problems have arisen from the application of dicofol. Bioremediation is an effective solution for dicofol persistence in the environment. In this study, a bacterial strain D-2, identified to genus Microbacterium, capable of degrading dicofol was isolated from dicofol-contaminated agricultural soil. This represents the first dicofol degrading bacterium isolated from this genus. Microbacterium sp. D-2 degraded $50 \mathrm{mg} / \mathrm{L}$ dicofol within $24 \mathrm{~h}$ at a rate of $85.1 \%$. Dicofol was dechlorinated by D-2 and the further degradation metabolite was indentified as p, $\mathrm{p}^{\prime}$-dichlorobenzophenone(DCBP). Soils inoculated with Microbacterium sp. D-2 degraded $81.9 \%$ of the dicofol, while soils without D-2 only degraded $20.5 \%$ of the dicofol present. This finding suggests that strain D-2 has great potential in bioremediation of dicofolcontaminated soils.
\end{abstract}

Keywords: Dicofol, Biodegradation, Microbacterium sp. D-2, Bioremediation

\section{Introduction}

Organochlorine pesticides (OCPs) are broad spectrum insecticides with high toxicity and long residual periods [1]. They have been widely used in the control of agricultural pests, antisepsis in industrial production and the treatment of human diseases, such as malaria [2]. However, they have a long half-life and bioaccumulate in the food chain [3], thus cause serious harm to human health and ecological environment [4-7].

Dicofol (DCF) is a typical representative of OCPs, with the chemical name 2,2,2-trichloro-1,1-bis(4-chlorophenyl) ethanol. As a broad spectrum acaricide, DCF is mostly used to prevent and control insect of tea, cotton, vegetables, citrus and other crops [8, 9]. DCF residues can affect ecosystems adversely, causing serious environmental pollution. More specifically, DCF high toxicity (i.e., carcinogenic, teratogenic, and mutagenic) could

*Correspondence: lupeng_2007@126.com

College of Life Sciences, Anhui Normal University, NO.1 Beijing East Road, Wuhu 241000, Anhui, China cause acute poising of fish and shrimp, endocrine disruptive properties, and chronic toxicity to other organisms [10-13]. Therefore, it is believed that DCF would exert a negative influence on both animals $[14,15]$ and humans [16]. Most developed countries have already prohibited the DCF application due to concerns about persistency and toxicity [17]. However, DCF residues in crops, especially in tea [18], remain as a serious problem. Its concentration still exceeds the standard due to its stable chemical property and long residual period, highlighting the need for removing residual DCF from the environment.

Chemical and biological degradation of DCF are the two major methods which have been widely studied at present (Table 1). In both, bioremediation is an effective method for the removal and degradation of residual pesticides $[19,20]$ as it exploits the potential of microbial degradation which is cost-effective and reliable [21]. A large number of microorganisms could be exploited for environment protection by complete mineralization or degradation of diverse toxic contaminants (e.g., organic pesticides, heavy metals) into 
Table 1 Comparison of chemical and biological degradation of dicofol

\begin{tabular}{|c|c|c|c|c|c|}
\hline Factor & $\begin{array}{l}\text { Initial } \\
\text { concentration } \\
\text { (mg/L) }\end{array}$ & Degradation rate and time & Advantages & Disadvantages & References \\
\hline \multicolumn{6}{|l|}{ Photochemical } \\
\hline $\mathrm{TiO}_{2}-\mathrm{NPs}$ & 10 & $100 \%$ in $2 \mathrm{~h}$ & High degradation rate & Low initial concentration & [31] \\
\hline $\begin{array}{l}\text { Boric/Cerous co-doped } \\
\mathrm{TiO}_{2}\end{array}$ & 0.2 & $83 \%$ in $0.5 \mathrm{~h}$ & Short time & Low initial concentration & [32] \\
\hline $\mathrm{Ag} / \mathrm{TiO}_{2}-\mathrm{NTs}$ & 100 & $72 \%$ in $20 \mathrm{~min}$ & $\begin{array}{l}\text { Short time and high initial } \\
\text { concentration }\end{array}$ & Low degradation rate & [33] \\
\hline \multicolumn{6}{|l|}{ Sonochemical } \\
\hline Hydrodynamic cavitation & 50 & $85 \%$ in $1 \mathrm{~h}$ & Short time & Difficult to apply & [34] \\
\hline \multicolumn{6}{|l|}{ Electrochemical } \\
\hline BDD electrode & 50 & $100 \%$ in $3 \mathrm{~h}$ & High degradation rate & High cost & {$[35]$} \\
\hline \multicolumn{6}{|l|}{ Oxidation } \\
\hline $\mathrm{H}_{2} \mathrm{O}_{2}$ & 0.6 & $100 \%$ in $100 \mathrm{~min}$ & High degradation rate & Low initial concentration & [36] \\
\hline $\mathrm{O}_{3}$ & 0.16 & $98 \%$ in $1 \mathrm{~h}$ & High degradation rate & Low initial concentration & {$[37]$} \\
\hline \multicolumn{6}{|l|}{ Biological } \\
\hline Pseudomonas sp. PFD9 & 10 & $70 \%$ in $24 \mathrm{~h}$ & $\begin{array}{l}\text { Low cost and easy to } \\
\text { operate }\end{array}$ & $\begin{array}{l}\text { Low initial concentration } \\
\text { and degradation rate }\end{array}$ & [30] \\
\hline Pseudomonas sp. PFD13 & 10 & $32 \%$ in $24 \mathrm{~h}$ & $\begin{array}{l}\text { Low cost and easy to } \\
\text { operate }\end{array}$ & $\begin{array}{l}\text { Low initial concentration } \\
\text { and degradation rate }\end{array}$ & \\
\hline $\begin{array}{l}\text { Exiguobacterium acetylicum } \\
\text { MA4 }\end{array}$ & 5 & $95 \%$ in $24 \mathrm{~h}$ & $\begin{array}{l}\text { High degradation rate and } \\
\text { low cost }\end{array}$ & Low initial concentration & [27] \\
\hline Bacillus megaterium SSF1 & 5 & $93 \%$ in $24 \mathrm{~h}$ & $\begin{array}{l}\text { High degradation rate and } \\
\text { low cost }\end{array}$ & Low initial concentration & \\
\hline Strain DSPM95 & 20 & $95 \%$ in 31 days & $\begin{array}{l}\text { High degradation rate and } \\
\text { low cost }\end{array}$ & Long time & [38] \\
\hline Datronia concentrica & 20 & $99 \%$ in 31 days & $\begin{array}{l}\text { High degradation rate and } \\
\text { low cost }\end{array}$ & Long time & \\
\hline Cellulase & 10 & $72 \%$ in $7 \mathrm{~h}$ & Easy to operate and obtain & $\begin{array}{l}\text { Low initial concentration } \\
\text { and degradation rate }\end{array}$ & {$[28]$} \\
\hline Activated sludge & 1 & $97 \%$ in 18 days & $\begin{array}{l}\text { Easy to obtain and high } \\
\text { degradation rate }\end{array}$ & $\begin{array}{l}\text { Low initial concentration } \\
\text { and anaerobic }\end{array}$ & [29] \\
\hline
\end{tabular}

small non-toxic molecules through various metabolic pathways [22-24]. However, limited data currently are available on bioremediation of DCF due to its high resistance against microbial degradation $[25,26]$. Strain MA4 which has high efficiency in DCF degradation (95.87\%), but the original concentration of DCF is only $5 \mathrm{mg} / \mathrm{L}$ [27]. Cellulase can degrade DCF, but it is not an organism but an enzyme [28]. Similarly, DCF is biodegraded during wastewater aerobic treatment and sludge anaerobic digestion, but DCF-biodegrading organisms could not be identified [29]. In addition, the degradation time of DCF by bacteria is relatively long, and the degradation efficiency is not high [30].

In this work, an efficient DCF-degrading bacterium was isolated from DCF-contaminated agricultural soil and was further characterized and identified. Additionally, the ability of strain for DCF degradation in liquid medium as well as soil was also studied for evaluating its efficiency in DCF-contaminated soil bioremediation.

\section{Materials and methods}

\section{i. Chemicals}

Dicofol (98\%, powder), purchased from Yiji Chemical Company. (Shanghai, China); Concentrated stock solutions of dicofol $(10 \mathrm{~g} / \mathrm{L})$ was prepared in dimethyl sulfoxide.

Methanol and acetonitrile (HPLC-grade), obtained from Shanghai Chemical Reagent Co. Ltd. (Shanghai, China). Ethyl acetate and all other reagents (analytical-reagent grade), purchased from Shanghai Chemical Reagent Co. Ltd. (Shanghai, China). 
PCR primer, DNA extraction kit and all other molecular biological reagents were obtained from Genscript Biological Science and Technology Co. Ltd. (Nanjing, China).

ii. Culture media

Medium for bacterial culture: Luria-Bertani (LB) medium contained $(\mathrm{g} / \mathrm{L})$ : tryptone 10.0 , yeast extract 5.0 and $\mathrm{NaCl}$ 10.0, $\mathrm{pH}$ 7.0. Medium for degradation experiment: The mineral salts medium (MSM) contained (g/L): $\mathrm{NH}_{4} \mathrm{NO}_{3} 1.0, \mathrm{~K}_{2} \mathrm{HPO}_{4} 1.5$, $\mathrm{KH}_{2} \mathrm{PO}_{4} 0.5, \mathrm{NaCl} 0.5, \mathrm{MgSO}_{4} 0.2, \mathrm{pH}$ 7.0. All the medium were sterilized by autoclaving at $121.3^{\circ} \mathrm{C}$ for $30 \mathrm{~min}$.

\section{Isolation and identification of dicofol-degrading strain}

Soil samples, collected from Jingxian City, Anhui Province, where tea was grown and DCF was applied. Five grams of soil sample was inoculated into MSM medium (100 mL in flasks) amended with $50 \mathrm{mg} / \mathrm{L} \mathrm{DCF}$ and the culture was incubated at $30{ }^{\circ} \mathrm{C}$ at $180 \mathrm{rpm}$ for 7 days. One milliliter of enrichment culture was transferred into fresh MSM medium at regular intervals of 1 week. Highperformance liquid chromatography (HPLC) was used to determine dicofol and confirm degradation. The enrichment culture was serially diluted and spread on MSM plates containing $50 \mathrm{mg} / \mathrm{L} \mathrm{DCF}$, then cultivated at $30{ }^{\circ} \mathrm{C}$ for 3 days. The colonies thus isolated were further purified by the streak plate method.

The 16S rDNA gene of the strain with degradation activity was amplified by PCR using standard procedures [39], and identified according to the Bergey's Manual of Determinative Bacteriology [40]. The nucleotide sequences were used for BLAST analysis against the NCBI database to identify the organism. Alignment of $16 \mathrm{~S}$ rDNA gene sequences from the GenBank database was performed using ClustalX 1.8.3 with default settings [41]. Phylogenesis was analyzed by MEGA, version 5.0 and an unrooted tree was built by the neighbor joining method [42].

\section{Degradation of dicofol by strain D-2 in liquid culture}

Strain D-2 was cultured to exponential phase in LB medium, and then collected by centrifugation at 6000 $g$ for $5 \mathrm{~min}$ at room temperature. The cell precipitation was washed twice with sterilized MSM and adjusted to approximately $2 \times 10^{8} \mathrm{CFU} / \mathrm{mL}$. For the degradation experiments in liquid culture, the cells were inoculated to approximately $1 \times 10^{7} \mathrm{CFU} / \mathrm{mL}$. Degradation experiment was carried out in $100 \mathrm{~mL}$ MSM containing $50 \mathrm{mg} / \mathrm{L}$ DCF. The culture was incubated at $30^{\circ} \mathrm{C}$ at $180 \mathrm{rpm}$ for $24 \mathrm{~h}$ after inoculation of the strain. Set DCF at two different concentrations $(20 \mathrm{mg} / \mathrm{L}$ and
$80 \mathrm{mg} / \mathrm{L}$ ) in the MSM, following the above method to analyze the degradation of DCF at different concentrations by strain D-2.

\section{Growth of strain D-2 in MSM culture}

Diluents ranging from $10^{-4}$ to $10^{-1}$ were obtained by tenfold gradient dilution. According to dilution plate counting method, $0.2 \mathrm{~mL}$ diluent was spread on LB plate and cultured at $30{ }^{\circ} \mathrm{C}$ for $48 \mathrm{~h}$. Plates with a colony number from 30 to 300 were selected for counting. All samples were in triplicate.

\section{Effects of culture conditions on degradation}

Inoculated strain D-2 in MSM medium in $250 \mathrm{~mL}$ flask containing $50 \mathrm{mg} / \mathrm{L}$ DCF. The cultures were incubated at the same conditions as discribed above except for the variables which need to be tested. Temperature experiment: Cultures were incubated at different temperatures $\left(20{ }^{\circ} \mathrm{C}, 25{ }^{\circ} \mathrm{C}, 30{ }^{\circ} \mathrm{C}, 37{ }^{\circ} \mathrm{C}, 42{ }^{\circ} \mathrm{C}\right)$. The $\mathrm{pH}$ experiment: Adjusted initial pH of the cultures to 4.0, 5.0, 6.0, 7.0, 8.0, 9.0, respectively. Oxygen demand experiment: Set different volumes $(20 \mathrm{~mL}, 50 \mathrm{~mL}, 100 \mathrm{~mL}, 150 \mathrm{~mL}, 200 \mathrm{~mL})$ of the medium to control ventilation amount. Mixing rate experiment: Set different shaking speeds $(0 \mathrm{rpm}$, $60 \mathrm{rpm}, 120 \mathrm{rpm}, 180 \mathrm{rpm}, 200 \mathrm{rpm}, 220 \mathrm{rpm}$ ) to control mixing rate. All the cultures were sampled to detected the concentrations of DCF after cultured for $24 \mathrm{~h}$.

\section{Extraction and HPLC detection of dicofol}

Cultures were regularly sampled for the determination of the concentrations of DCF and cell growth with every $12 \mathrm{~h}, 2 \mathrm{~mL}$ each time. Three volumes of ethyl acetate was added to each sample. The organic phase was retained after an intense mixing for $15 \mathrm{~s}$. The sample was then dried and re-dissolved with $2 \mathrm{~mL}$ methanol.

The degradation products were analyzed by reversephase HPLC with C-18 column $(150 \mathrm{~mm} \times 4.6 \mathrm{~mm}$, $5 \mu \mathrm{m})$ equipped with UV detector. The mobile phase containing acetonitrile/water $(85: 15, \mathrm{v} / \mathrm{v})$ was delivered at a flow rate of $0.8 \mathrm{~mL} / \mathrm{min}$ at $25{ }^{\circ} \mathrm{C}$. The detection wavelength was set at $230 \mathrm{~nm}$. The concentration of DCF was determined by comparison with values in the calibration curve established by concentrations between 1 and $100 \mathrm{mg} / \mathrm{L}$. The limits of detection (LOD) and quantification (LOQ) were 0.016 and $0.057 \mathrm{mg} / \mathrm{L}$, respectively. The recovery and RSD were $86.5-92.5 \%$ and $1.10-2.84 \%$ at concentrations ranging from 1 to $100 \mathrm{mg} / \mathrm{L}$.

\section{Degradation of dicofol by strain D-2 in soil}

Soil used for the experiment was collected from Anhui Normal University campus that had no previous exposure to DCF. The soil was air-dried, sieved to $2 \mathrm{~mm}$, and 
homogenized immediately after collection. Glass beaker $(200 \mathrm{~mL})$ microcosms, each containing $100 \mathrm{~g}$ soil, were spiked with DCF (50 mg/kg soil). For the inoculated set of beakers, MSM medium $(4.0 \mathrm{~mL})$ containing strain D-2 was added, and the final concentration was $1 \times 10^{7}$ cells $/ \mathrm{g}$ of soil. On the contrary, MSM medium $(4.0 \mathrm{~mL})$ with no strain added was used for the set of non-inoculated beakers. Triplicate soil samples were prepared for two sets of treatments, and each soil sample was incubated at $30{ }^{\circ} \mathrm{C}$ under sterile conditions. During incubation, the soil microcosms were weighed regularly, and weight loss was compensated by the addition of water. Soil samples $(5 \mathrm{~g})$ were collected for the analysis of DCF concentration every 7 days for 42 days.

\section{Results and discussion}

\section{Isolation and identification of strain D-2}

Only a few publications have reported the microbial degradation of DCF up to date (Table 2), and the germplasm resources need to be abundant. Through enrichment culture and serial dilution, spread plating was done to obtain growth in this study. From the colonies, a bacterium capable of degrading DCF was isolated and named strain $\mathrm{D}-2$. This strain is gram-positive, positive for catalase and urease activity, negative for hydrolysis of amylum, gelatin, and production of indole. Molecular identification was done by $16 \mathrm{~S}$ rDNA typing. Comparative analysis of the $16 \mathrm{~S}$ rDNA gene sequence of strain D-2 illustrated high similarity with those of species of the genus
Microbacterium. This represents the first DCF degrading bacterium isolated from this genus. The sequence was deposited in GenBank under Accession No. MN061021. Phylogenetic analysis clustered strain D-2 within the clade of Microbacterium and phylogenetic tree was built based on 16S rDNA sequences (Fig. 1).

\section{Degradation of dicofol by strain D-2 in liquid culture}

The previous study has shown that seven strains of bacteria and two strains of fungi were capable of degrading dicofol efficiently with degradation efficiency of 75-94\% and 92-96\% within 28 days, respectively [25]. Pseudomonas sp. P9 and Pseudomonas sp. P13 degraded DCF at a concentration of $10 \mathrm{mg} / \mathrm{L}$, the degradation rate was $38 \%$ and $14.2 \%$, respectively. After adding glucose in the culture medium, the degradation rate increased to $70 \%$ and $32 \%$, respectively [30]. However, the degradation rate of the strains and initial pesticide concentration were very low. Strain MA4 had high efficiency in DCF degradation (up to $95.87 \%$ ), but the original concentration of DCF was only $5 \mathrm{mg} / \mathrm{L}$ [27]. In summary, efficient DCF degrading bacterium is very few.

Figure 2a shows the degradation of DCF and growth of strain D-2. There was no significant change in the concentration of DCF and the amount of bacteria during the first $4 \mathrm{~h}$. This is attributed to the fact that the strain need adaptation to a new environment and enzymes relevant to degradation have not been synthesized. During the next 4-12 h, the concentration of DCF decreased and the

Table 2 Comparison of the reported dicofol-degrading microorganisms

\begin{tabular}{|c|c|c|c|c|c|c|}
\hline Genera & Strain & From & $\begin{array}{l}\text { Initial } \\
\text { concentration } \\
\text { (mg/L) }\end{array}$ & Degradation efficiency & Product & References \\
\hline Pseudomonas & P. PFD9 & India (Tea rhizosphere soil) & 10 & $70 \%$ in $24 \mathrm{~h}$ & Unknown & {$[30]$} \\
\hline Pseudomonas & P. PFD13 & & & $32 \%$ in $24 \mathrm{~h}$ & & \\
\hline Exiguobacterium & E. acetylicum MA4 & Thailand (DCF-polluted soil) & 5 & $95 \%$ in $24 \mathrm{~h}$ & & {$[27]$} \\
\hline Bacillus & B. megaterium SSF1 & & & $93 \%$ in $24 \mathrm{~h}$ & & \\
\hline Trametes & T.pocas & Zimbabwe (dead wood in woodlands) & 20 & $97 \%$ in 31 days & & {$[38]$} \\
\hline Unknow & DSPM95 & & & $95 \%$ in 31 days & & \\
\hline Datronia & D. concentrica & & & $99 \%$ in 31 days & & \\
\hline Pycnoporus & P. sanguineus & & & $99 \%$ in 31 days & & \\
\hline Azospirillium & A. barasilense & Egypt (College of Agriculture, Alexandria & 100 & $75 \%$ in 28 days & & {$[25]$} \\
\hline Azotobacter & A. chroococcum & & & $94 \%$ in 28 days & & \\
\hline Klebsilense & K.pneumoneae & & & $88 \%$ in 28 days & & \\
\hline Pseudomonas & P. cepacia & USA (type culture collection) & & $87 \%$ in 28 days & & \\
\hline Bacillus & B. subtilis & Egypt (soil of the wheat fields) & & $85 \%$ in 28 days & & \\
\hline Pseudomonas & P. fluorescens & & & $82 \%$ in 28 days & & \\
\hline Bacillus & B. polymyxa & $\begin{array}{l}\text { Saudi Arabia (wheat roots of Al-Qassim } \\
\text { fields) }\end{array}$ & & $84 \%$ in 28 days & & \\
\hline Microbacterium & M.D-2 & China (DCF-polluted agricultural soil) & 50 & $84 \%$ in $24 \mathrm{~h}$ & DCBP & This work \\
\hline
\end{tabular}




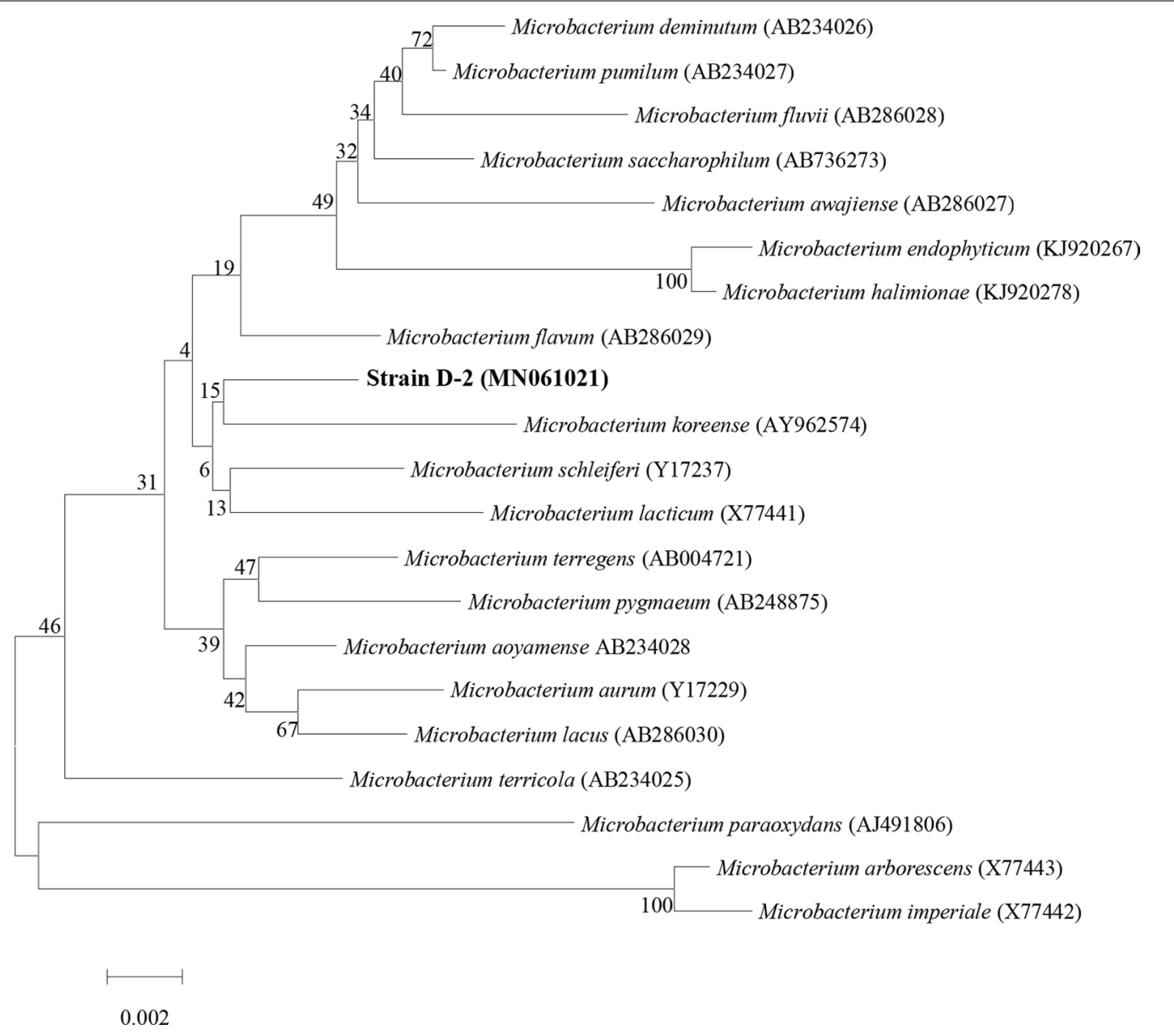

Fig. 1 Neighbor-joining tree showing the phylogenetic relationship between strain D-2 and related species based on the 16S rDNA gene sequences

bacterial population increased rapidly, which indicating the degradation of DCF as carbon source by strain D-2 because of strain D-2 was not capable of utilizing dimethyl sulfoxide as sole carbon source for growth in MSM medium. After $12 \mathrm{~h}$, the increase of biomass and the decrease of DCF became slower, indicating the growth and degradation function of strain D-2 had reached the maximum. The final degradation efficiency is $85.1 \%$. As a control, degradation of DCF was negligible in MSM medium without the inoculation of strain D-2. The result of degradation of DCF at different concentrations $(20 \mathrm{mg} / \mathrm{L}, 50 \mathrm{mg} / \mathrm{L}, 80 \mathrm{mg} / \mathrm{L}$ ) by strain D-2 are shown in Fig. 2b. The degradation rate decreased gradually from low to high concentration. DCF $(20 \mathrm{mg} / \mathrm{L})$ was completely degraded in $16 \mathrm{~h}$. Compared with strain PFD9, which could degrade $10 \mathrm{mg} / \mathrm{L}$ DCF within $24 \mathrm{~h}$ at a rate of $70 \%$ (Table 2). The degradation efficiency of strain D-2 was much higher.

Whereas only $67.7 \%$ DCF was degraded in the group with higher concentration $(80 \mathrm{mg} / \mathrm{L})$ with prolonged incubation $(24 \mathrm{~h})$, and the degadation rate was lower. But at similar time more DCF at concentration of $80 \mathrm{mg} / \mathrm{L}$ was degraded, compared with the sample containing $20 \mathrm{mg} / \mathrm{L} \mathrm{DCF}$ as shown in Fig. 2b. This may be attributed to more carbon nutrition provided by high concentration of DCF which caused more vigorous growth of strain D-2 in the first $16 \mathrm{~h}$. Then growth of the bacterial strain was basically stagnant due to depletion of nitrogen sources or other nutrients in the medium. And the remaining DCF would not be degraded further in the last $8 \mathrm{~h}$.

\section{Effects of culture conditions on degradation}

The suitable temperature for degradation was ranging from 25 to $37^{\circ} \mathrm{C}$, and the optimal temperature was $30^{\circ} \mathrm{C}$. Lower and higher temperatures were not conducive to degradation due to the inhibition of synthesis and activity of degrading enzymes (Additional file 1: Fig. S1). The degradation rates were more than $70 \%$ at $\mathrm{pH} 6.0-8.0$, and the optimal $\mathrm{pH}$ was 7.0. In both acidic and alkaline 

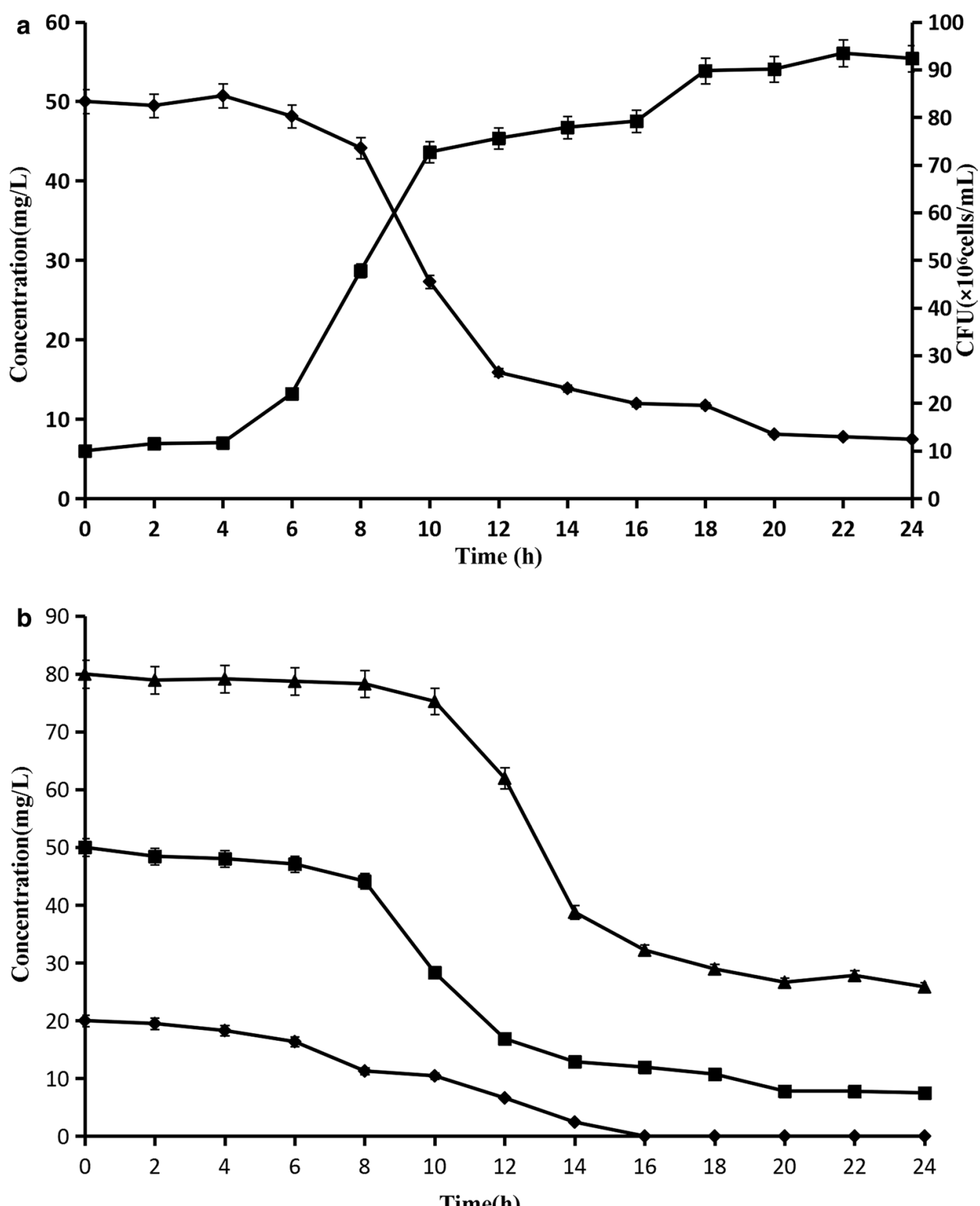

Fig. 2 a Growth of the strain and degradation of dicofol. (Filled square) Cell density; (filled diamond) concentration of dicofol. b The effect of different initial concentration on the degradation of dicofol. (Filled triangle) $80 \mathrm{mg} / \mathrm{L}$ as the initial concentration dicofol; (Filled square) $50 \mathrm{mg} / \mathrm{L}$ as the initial concentration dicofol; (Filled diamond) $20 \mathrm{mg} / \mathrm{L}$ as the initial concentration dicofol

environment, the degradation rates were lower than that in the neutral environment. This was determined by the growth and enzyme characteristics of the strain (Additional file 2: Fig. S2). When the liquid volume was less than $100 \mathrm{~mL}$, the degradation rates could reach a maximum of about $85 \%$ due to sufficient oxygen. As volume increased, the degradation efficiency decreased due to a reduction in the amount of oxygen (Additional file 3:
Fig. S3). Which indicated strain D-2 was an aerobic bacterium. The mixing of strain D-2 with nutrients and DCF were insufficient when the shaking speed was lower than $180 \mathrm{rpm}$ and the degradation rate increased with mixing rate. When the shaking speed was more than $180 \mathrm{rpm}$, the degradation rate was the highest and had no increase with shaking speed due to the maximum of mixing rate (Additional file 4: Fig. S4). 


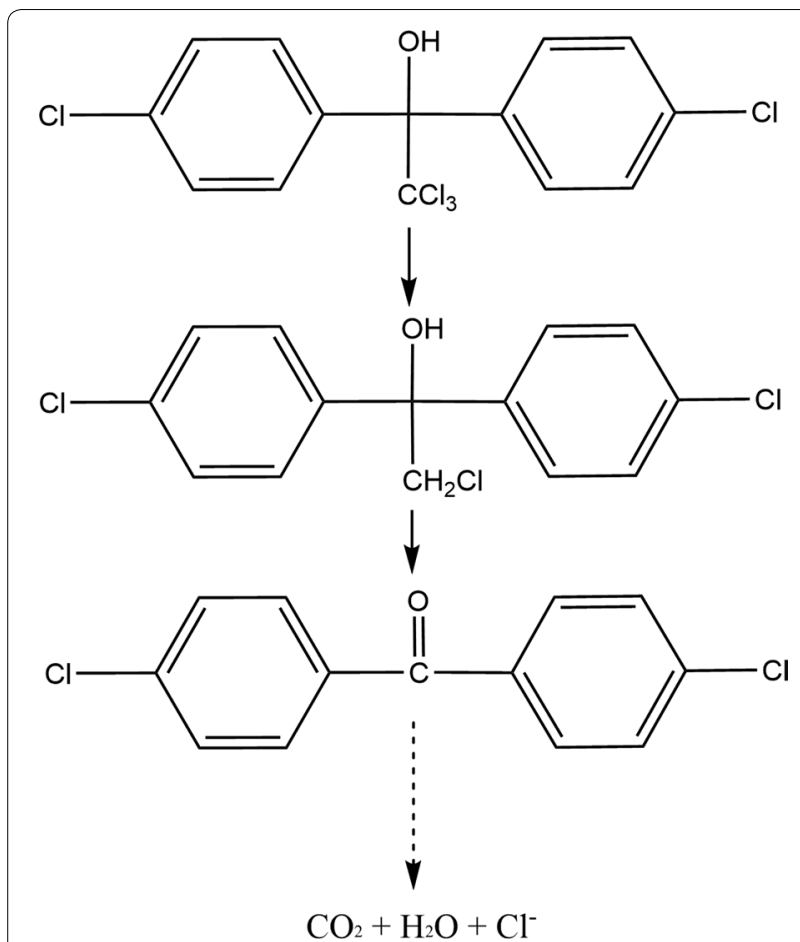

Fig. 3 The proposed degradation pathway of dicofol by strain D-2

\section{HPLC and MS analysis}

DCF and its metabolites were detected by HPLC. DCF was used as an initial substrate that showed a retention time of $7.803 \mathrm{~min}$ (Additional file 5: Fig. S5). For the sample collected $10 \mathrm{~h}$ after inoculation, three compounds were detected by HPLC, with retention times of 4.342, 5.982 and $7.797 \mathrm{~min}$ (Additional file 6: Fig. S6), respectively, one was DCF and the other two were its metabolite. The sample was analyzed with MS, the prominent protonated molecular ion of compound A was at $\mathrm{m} / \mathrm{z}=366.91-372.92[\mathrm{M}-\mathrm{H}]^{-}$and identified as DCF (Additional file 7: Fig. S7). Compounds B ( $\mathrm{m} / \mathrm{z}=298.98-$ $302.98[\mathrm{M}-\mathrm{H}]^{-}$) (Additional file 8: Fig. S8) was the degradation metabolite and formed by the dechlorination of DCF, while Compound $\mathrm{C}$ at $\mathrm{m} / \mathrm{z}=249.01-252.99$ $[\mathrm{M}-\mathrm{H}]^{-}$(Additional file 9: Fig. S9) was the metabolite produced from the further degradation of compound $B$, and indentified as $\mathrm{p}, \mathrm{p}^{\prime}$-dichlorobenzophenone (DCBP). For the sample collected $24 \mathrm{~h}$ after inoculation, three compounds with similar property as the sample collected at $10 \mathrm{~h}$ incubation were detected by HPLC chromatography (Additional file 10: Fig. S10). But the total concentration of the three compounds was lower than that in the sample at $10 \mathrm{~h}$, suggesting that the metabolite was further degraded by D-2. Since strain D-2 can use DCF as the sole carbon source for growth (Fig. 2a) and dechlorination of DCF cannot produce a carbon source, the organism must cleave the ring of the metabolite. Based on the result of HPLC and MS, we derived the degradation pathway of DCF by strain D-2 (Fig. 3).

\section{Degradation of dicofol by strain D-2 in soil}

The result of degradation of DCF in the soil is shown in Fig. 4. The sample inoculated with strain D-2 resulted

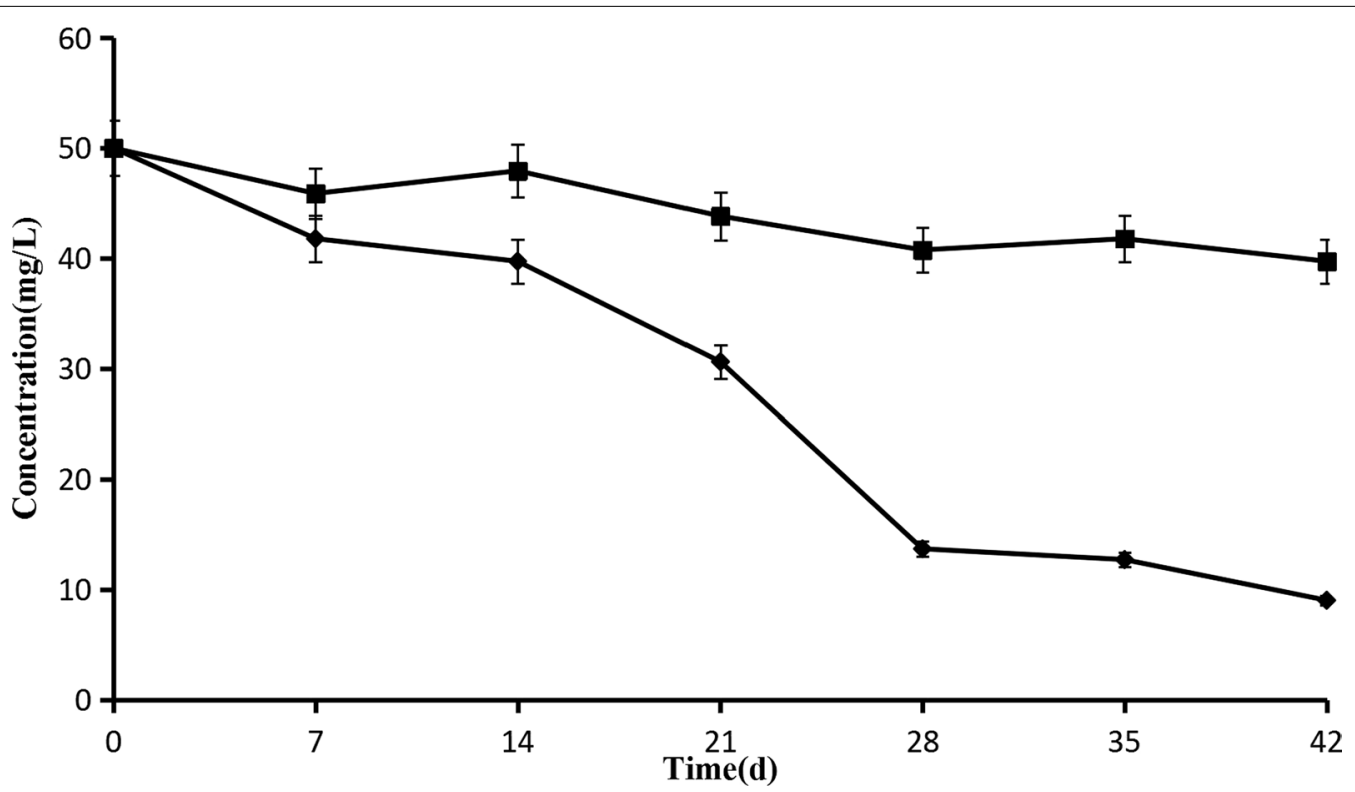

Fig. 4 Degradation of dicofol in the soil by strain D-2. (Filled diamond) Concentration of dicofol in the soil inoculated with strain D-2; (filled square) concentration of dicofol in the control soil 
in a higher degradation rate, the concentration of DCF dropped from 50 to $9.01 \mathrm{mg} / \mathrm{kg}$ and most degradation occurred between 14 and 28 days, with a high degradation rate of $81.9 \%$. In uninoculated soil, only about $20.5 \%$ of DCF was degraded naturally in 42 days. The result indicates that strain D-2 is capable of degrading DCF in the soil and can be used for bioremediation.

Pollution caused by organochlorine pesticides is widespread all over the world [43]. Although most OCPs were banned between the 1970s and 1990s, they may still remain in the soil due to their persistent physical and chemical properties [44, 45]. It has been reported that OCPs are distributed throughout the globe including regions where they were not or have never been used [46]. Therefore, the environmental consequences of OCPs remains to be a serious concern today and the pesticide residues pose a serious threat to human health and ecological security. In nature, microorganisms are frequently the major means responsible for the degradation of chemical contaminants [47]. Since bioremediation is a rapid, cost-effective, and environmentally friendly method with no secondary pollution, it offers a promising strategy to remove pesticide residues in the environment [48]. Therefore, it is of great theoretical and practical significance to isolate and screen efficient DCF degrading bacteria.

\section{Supplementary information}

Supplementary information accompanies this paper at https://doi. org/10.1186/s13765-019-0480-y. Additional file 1: Fig. S1. Effect of temperature on degradation of dicofol
by strain D-2.

Additional file 2: Fig. S2. Effect of $\mathrm{pH}$ on degradation of dicofol by strain D-2.

Additional file 3: Fig. S3. Effect of oxygen on degradation of dicofol by strain D-2.

Additional file 4: Fig. S4. Effect of mixing rate on degradation of dicofol by strain $\mathrm{D}-2$.

Additional file 5: Fig. S5. HPLC spectrum of dicofol.

Additional file 6: Fig. S6. HPLC chromatogram of dicofol and its metabolite after inoculation with D-2 for $10 \mathrm{~h}$.

Additional file 7: Fig. S7. MS detection of Compound A.

Additional file 8: Fig. S8. MS detection of Compound B.

Additional file 9: Fig. S9. MS detection of Compound C.

Additional file 10: Fig. S10. HPLC chromatogram of dicofol and its metabolite after inoculation with D2 for $24 \mathrm{~h}$.

\section{Acknowledgements}

This work was supported by Grant from Anhui National Natural Science Foundation (1708085QC67). The authors are grateful to Anhui Provincial Key Lab. of the Conservation and Exploitation of Biological Resources.

\section{Authors' contributions}

$\mathrm{P}$ isolated the bacterium, detected the metabolites of dicofol, and was the major contributor in writing the manuscript. HM researched he growth and degradation characteristics of the strain. AM carried out the experiment of dicofol degradation by the strain in the soil. All authors read and approved the final manuscript.

\section{Funding}

This research was supported by a Grant (1708085QC67) from Anhui National Natural Science Foundation.

\section{Availability of data and materials}

All data analysed during this study are included in this published article.

\section{Competing interests}

The authors declare that they have no competing interests.

Received: 15 October 2019 Accepted: 2 December 2019

Published online: 12 December 2019

\section{References}

1. El-Shahawia MS, Hamza A, Bashammakhb AS, Al-Saggaf WT (2010) An overview on the accumulation, distribution, transformations, toxicity and analytical methods for the monitoring of persistent organic pollutants. Talanta 80:1587-1597

2. Xu XP, Xi YL, Chu ZX, Xiang XL (2013) Effects of DDT and dicofol on population growth of Brachionus calyciflorus under different algal (Scenedesmus obliquus) densities. J Environ Biol 35:907-916

3. Poolpak T, Pokethitiyook P, Kruatrachue M, Arjarasirikoon U, Thanwaniwat N (2008) Residue analysis of organochlorine pesticides in the Mae Klong riverof Central Thailand. J Hazard Mater 156:230-239

4. Katsoyiannis A, Samara C (2005) Persistent organic pollutants (POPs) in the conventional activated sludge treatment process, fate and mass balance. Environ Res 97:245-257

5. Shen L, Wania F (2005) Compilation, evaluation, and selection of physical-chemical property data for organochlorine pesticides. J Chem Eng Data 50(3):742-768

6. Qiu YW, Zeng EY, Qiu HL, Yu KF, Cai SQ (2017) Bioconcentration of polybrominated diphenyl ethers and organochlorine pesticides in algae is an important contaminant route to higher trophic levels. Sci Total Environ 579:1885-1893

7. Lenters V, Lszatt N, Forns J, Čechová E, Kočan A, Legler J, Leonards P, Stigum H, Eggesb M (2019) Early-life exposure to persistent organic pollutants (OCPs, PBDEs, PCBs, PFASs) and attention-deficit/hyperactivity disorder: a multi-pollutant analysis of a Norwegian birth cohort. Environ Int 125:33-42

8. Kitajama EW, Rezende JAM, Rodrigues JCV (2003) Passion fruit green spot virus vectored by Brevipalpusphoenicis (Acari: Tenuipalpidae) on passion fruit in Brazil. Exp Appl Acarol 30:25-231

9. Qiu XH, Zhu T, Yao B, Hu JX, Hu SW (2005) Contribution of dicofol to the current DDT pollution in China. Environ Sci Technol 39:4385-4390

10. Wang YZ, Zhang SL, Cui WY, Meng XZ, Tang XQ (2018) Polycyclic aromatic hydrocarbons and organochlorine pesticides in surface water from the Yongding River basin, China: seasonal distribution, source apportionment, and potential risk assessment. Sci Total Environ 618:410-429

11. Grisolia CK (2002) A comparison between mouse and fish micronucleus test using cyclophosphamide, mitomycin $C$ and various pesticides. Mutat Res 518(2):145-150

12. Ahmad A, Ahmad M (2017) Deciphering the toxic effects of organochlorine pesticide, dicofol on human RBCs and lymphocytes. Pestic Biochem Phys 143:127-134

13. Debabrata P, Sivakumar M (2018) Sonochemical degradation of endocrine-disrupting organochlorine pesticide dicofol: investigations on the transformation pathways of dechlorination and the influencing operating parameters. Chemosphere 204:101-108 
14. Jadaramkunti UC, Kaliwal BB (2002) Dicofol formulation induced toxicity on testes and accessory reproductive organism albino rats. Bull Environ Contam Toxicol 69(7):741-748

15. Kojima H, Katsura E, Takeuchi S, Niiyama K, Kobayashi K (2004) Screening for estrogen and androgen receptor activities in 200 pesticides by in vitro reporter gene assays using Chinese hamster ovary cells. Environ Health Persp 112(5):524-531

16. Reynolds P, Behren JV, Gunier RB, Goldberg DE, Harnly M, Hertz A (2005) Agricultural pesticide use and childhood cancer in California. Epidemiology 16(1):93-100

17. Li L, Liu JG, Hu JX (2015) Global inventory, long-range transport and environmental distribution of dicofol. Environ Sci Technol 49(1):212-222

18. Zhang J, Zhao Z, Wang L, Zhu X, Lan X (2016) Investigation of 2D correlation fluorescence spectrum of pesticide residual in tea. J Adv Chem Sci 2(1):170-173

19. Chen M, Xu P, Zeng GM, Yang CP, Huang DL, Zhang JC (2015) Bioremediation of soils contaminated with polycyclic aromatic hydrocarbons, petroleum, pesticides, chlorophenols and heavy metals by composting: applications, microbes and future research needs. Biotechnol Adv 33(6):745-755

20. Jaiswal S, Singh DK, Shukla P (2019) Gene editing and systems biology tools for pesticide bioremediation: a review. Front Microbiol. https://doi. org/10.3389/fmicb.2019.00087

21. Akbar S, Sultan S (2016) Soil bacteria showing a potential of chlorpyrifos degradation and plant growth enhancement. Braz J Microbiol 47(3):563-570

22. Tang W (2018) Research progress of microbial degradation of organophosphorus pesticides. Prog Appl Microbiol 1:29-35

23. Hamedi J, Dehhaghi M, Mohammdipanah F (2015) Isolation of extremely heavy metal resistant strains of rare actinomycetes from high metal content soils in Iran. Int J Environ Res 9(2):475-480

24. Mulla SI, Hu A, Sun Q, Li J, Suanon F, Ashfaq M, Yu CP (2018) Biodegradation of sulfamethoxazole in bacteria from three different origins. J Environ Manage 206:93-102

25. Osman KA, Ibrahim GH, Askar Al, Alkhail ARA (2008) Biodegradation kinetics of dicofol by selected microorganisms. Pestic Biochem Phys 91:180-185

26. Utami WN, labal R, Wenten IG (2010) Rejection characteristics of organochlorine pesticides by pressure reverse osmosis membrane. JAI 6(2):103-107

27. Tipsode P, Cheunbarn S (2015) Biodegradation of dicofol by bacteria isolated from agricultural soils. J Agric Res Ext 32(3):21-30

28. Zhai ZH, Yang T, Zhang BY, Zhang JB (2015) Effects of metal ions on the catalytic degradation of dicofol by cellulase. J Environ Sci 33:163-168

29. Oliveira JLM, Silva DP, Martins EM, Langenbach T, Dezotti M (2012) Biodegradation of 14C-dicofol in wastewater aerobic treatment and sludge anaerobic biodigestion. Environ Technol 33(6):695-701

30. Sarkar S, Satishkumar A, Premkumar R (2009) Biodegradation of dicofol by Pseudomonas strains isolated from tea rhizosphere microflora. Inter J Integrative Biol 5(3):164-166

31. Yu BB, Zeng JB, Gong LF, Yang XQ, Zhang LM, Chen X (2008) Photocatalytic degradation investigation of dicofol. Chin Sci Bull 53(1):27-32

32. Gong LF, Zou J, Zeng JB, Chen WF, Chen X, Wang XR (2009) Photocatalytic degradation of dicofol and pyrethrum with boric and cerous co-doped $\mathrm{TiO}_{2}$ under light irradiation. Chin J Chem 27:88-92

33. Guo G, Yu B, Yu P, Chen X (2009) Synthesis and photocatalytic applications of Ag/TiO2-nanotubes. Talanta 79:570-575

34. Panda D, Manickam S (2019) Hydrodynamic cavitation assisted degradation of persistent endocrine-disrupting organochlorine pesticide dicofol: optimization of operating parameters and investigations on the mechanism of intensification. Ultrason Sonochem 51:526-532
35. Id El Mouden O, Errami M, Salghi R, Zarrouk A, Zarrok H, Hammouti B (2012) oxidation of the pesticide dicofol at boron-doped diamond electrode. J Chem Acta 1:44-48

36. Mohammed S, Fasnabi PA (2016) Removal of dicofol from waste-water using advanced oxidation process. Procedia Technol 24:645-653

37. Ormad P, Puig A, Sarasa J, Roche P, Martin A, Ovelleiro JL (1994) Ozonation of waste-water resulting from the production of organochlorine plaguicides derived from DDT and trichlorobenzene. Ozone Sci Eng 16(6):487-503

38. Tekere M, Read JS, Mattiasson B (2010) An evaluation of organopollutant biodegradation by some selected white rot fungi: an overview. WIT Trans Ecol Environ 132:131-141

39. Lane DJ (1991) 16S/23S rRNA sequencing. In: Stackebrandt E, Goodfellow $M$ (eds) Nucleic acid techniques in bacterial systematics. Wiley, New York, pp 371-375

40. Holt JG, Krieg NR, Sneath PHA, Staley JT, William ST (1994) Bergey's manual of determinative bacteriology, 9th edn. Lippincott Williams and Wilkins, Baltimore

41. Thompson JD, Gibson TJ, Plewniak F, Jeanmougin F, Higgins DG (1997) The CLUSTAL_X windows interface. Flexible strategies for multiple sequence alignment aided by quality analysis tools. Nucleic Acids Res 25(24):4876-4882

42. Weisburg WG, Barns SM, Pelletier DA, Lane DJ (1991) 16S ribosomal DNA amplification for phylogenetic study. J Bacteriol 173(2):697-703

43. Cai QY, Mo CH, Wu QT, Katsoyiannis A, Zeng QY (2008) The status of soil contamination by semivolatile organic chemicals (SVOCS) in China: a review. Sci Total Environ 389:209-224

44. Mahmoud AFA, Ikenaka Y, Yohannes YB, Darwish WS, Eldaly EA, Morshdy AE, Morshdy AEMA, Nakayama SMM, Mizukawa H, Ishizuka M (2016) Distribution and health risk assessment of organochlorine pesticides (OCPs) residue in edible cattle tissues from northeastern part of Egypt: high accumulation level of OCPs in tongue. Chemosphere 144:1365-1371

45. Song C, Zhang JW, Hu GD, Yin Y, Qiu LP, Fan LM, Zheng Y, Meng SL, Zhang C, Chen JZ (2019) Effects of organochlorine pesticides (OCPs) on survival and edibility of loaches in the World Heritage Honghe Hani Rice Terraces, China. Aquacult Env Interaction 11:239-247

46. Isogai N, Hogarh JN, Seike N, Kobara Y, Oyediran F, Wirmvem MJ, Ayonghe SN, Fobil J, Masunaga S (2018) Atmospheric monitoring of organochlorine pesticides across some West African countries. Environ Sci Pollut R 25(32):31828-31835

47. Kumar A, Bisht BS, Joshi VD, Dhewa T (2011) Review on bioremediation of polluted environment: a management tool. Int J Environ Sci 1(6):1079-1093

48. Zheng YL, Liu DL, Liu SW, Xu SY, Yuan YZ, Xiong L (2009) Kinetics and mechanisms of $\mathrm{p}$-nitrophenol biodegradation by Pseudomonas aeruginosa HS-D38. J Environ Sci 21:1194-1199

\section{Publisher's Note}

Springer Nature remains neutral with regard to jurisdictional claims in published maps and institutional affiliations. 